\title{
Crystal Structure of $N$-Methyl-3-t-isopropyl-r-2,c-6-diphenylpiperidin-4-one
}

\author{
N. Sampath, ${ }^{*}$ S. Aravindhan, ${ }^{*}$ M. N. Ponnuswamy, ${ }^{* \dagger}$ and M. NethajI** \\ *Department of Crystallography and Biophysics, University of Madras, \\ Guindy Campus, Chennai 600 025, India \\ **Department of Inorganic and Physical Chemistry, Indian Institute of Science, Bangalore 560012 , India
}

\begin{abstract}
$N$-Methyl-3- $t$-isopropyl- $r$-2,c-6-diphenylpiperidin-4-one (NMIDPPO), crystallizes in monoclinic space group $P 2{ }_{1} / c$ with $a=16.666(6), b=12.349(5), c=18.778(7) \AA ; \beta=111.74(1)^{\circ}, V=3590(2) \AA^{3}, Z=8, D_{\text {cal }}=1.138 \mathrm{Mg} / \mathrm{m}^{3}$. The structure was solved by direct methods and refined by full-matrix least-squares procedures to a final $R$-value of 0.0556 for 5078 observed reflections. There are two crystallographically independent molecules in the asymmetric unit. The piperidine rings in both molecules adopt the chair conformation with the planar phenyl rings substituted equatorially at the 2,6 positions. The $\mathrm{C}-\mathrm{H} \cdots \mathrm{O}$ type of intermolecular hydrogen bonds and $\mathrm{C}-\mathrm{H} \cdots \pi$ weak interactions stabilize the molecules in the unit cell in addition to the van der Waals forces.
\end{abstract}

(Received November 22, 2004; Accepted February 14, 2005; Published on web May 13, 2005)

Piperidine derivatives are found to possess many pharmacological activities, such as antihistaminic, ${ }^{1}$ oral anaesthetics, norcotic analgesic and postganglionic parasympathetic agonists and to form an essential part of the molecular structure of important drugs. Particularly, 2,6disubstituted piperidine derivatives are used clinically to prevent post-operative vomiting, to speed up gastric emptying before anaesthesia and to correct a variety of disturbances of gastrointestinal functions, hypotensive activity, ${ }^{2}$ as well as bactericidal, fungicidal and herbicidal activities. Many piperidine derivatives also form the skeleton of several alkaloids. As a part of our ongoing studies concerning piperidine derivatives, the crystal structure of the title compound (Fig. 1) was analyzed in order to establish the molecular structure and stereochemistry.

The title compound was prepared by a Mannich condensation reaction using benzaldehyde $(2 \mathrm{~mol})$, ammonium acetate (1 mol) and 2-methylpentane-4-one $(1 \mathrm{~mol})$ in ethanol, and was then heated on a hot plate to the boiling range. The reacting product, 3-isopropyl-2,6-diphenylpiperidin-4-one was treated with $\mathrm{CH}_{3} \mathrm{I}$ in the presence of $\mathrm{K}_{2} \mathrm{CO}_{3}$ into dry acetone, and stirred for $5 \mathrm{~h}$ at $0^{\circ} \mathrm{C}$. The reaction mixture was poured into crushed ice, and a white precipitate was recrystallized using methanol.

The crystal structure and other experimental details are given in Table 1. The structure was solved by direct methods and

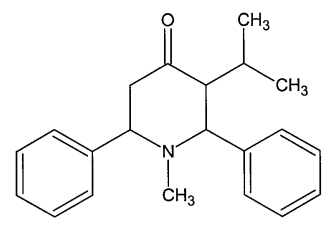

Fig. 1 Chemical diagram of NMIDPPO.

\section{CCDC No. CCDC 247429}

† To whom correspondence should be addressed.

E-mail: mnpsy2004@yahoo.com refined on $F^{2}$ by full-matrix least-squares procedures to a final $R$-value of 0.0556 . All of the hydrogen atoms were located from the difference Fourier procedure and refined isotropically. The atomic coordinates along with their equivalent isotropic displacement factors for non-hydrogen atoms are presented in Table 2.

There are two molecules in the asymmetric unit (A and B). It is interesting to note that the moleculer structures of $\mathrm{A}$ and $\mathrm{B}$ are almost in the same conformation, and the RMS-fit reveals a

Table 1 Crystal and experimental data

\begin{tabular}{ll}
\hline CCDC No. & CCDC 247429 \\
Empirical formula & $\mathrm{C}_{21} \mathrm{H}_{25} \mathrm{NO}$ \\
Formula weight & 307.42 \\
Measurement Temperature & $293(2) \mathrm{K}$ \\
Wavelength & $0.71073 \AA$ \\
Crystal system & monoclinic \\
Space group, Z & $P 2_{1} / c, 8$ \\
Unit cell dimensions & $16.666(6) \AA$ \\
$\quad a$ & $12.349(5) \AA$ \\
$b$ & $18.778(7) \AA$ \\
$c$ & $111.74(1)^{\circ}$ \\
$\beta$ & $3590(2) \AA^{3}$ \\
Volume & $1.138 \mathrm{Mg} / \mathrm{m}^{3}$ \\
$D_{\mathrm{x}}$ & $0.069 \mathrm{~mm}^{-1}$ \\
Absorption coefficient & $27.22^{\circ}$ with Mo $K_{\alpha}$ \\
$\theta_{\text {max }}$ & $27630 / 7406\left[R_{\text {int }}=0.0293\right]$ \\
Reflections/unique & 5078 \\
No. of reflections observed & \\
$(I \geq 2 \sigma(I))$ & 0.0556 \\
Final $R$ & 0.000 \\
$(\Delta / \sigma)_{\max }$ & Siemens SMART CCD Area \\
Measurement & Detector \\
& SHELX \\
Program system & Direct methods \\
Structure determination & 0.395 and -0.291 e $\AA^{-3}$ \\
Largest diff. peak and hole & full-matrix least-squares on $F^{2}$ \\
Refinement method & \\
&
\end{tabular}


Table 2 Atomic coordinates $\left(\AA \times 10^{4}\right)$ and equivalent isotropic displacement parameters $\left(\AA^{2} \times 10^{3}\right)$ involving non-hydrogen atoms.

\begin{tabular}{|c|c|c|c|c|c|c|c|c|}
\hline \multicolumn{5}{|c|}{ Molecule A } & \multicolumn{4}{|c|}{ Molecule B } \\
\hline Atom & $x$ & $y$ & $z$ & $U_{\text {eq }}$ & $x$ & $y$ & $z$ & $U_{\text {eq }}$ \\
\hline $\mathrm{N} 1$ & $8652(1)$ & $-1983(1)$ & $4306(1)$ & $49(1)$ & $8108(1)$ & $871(1)$ & $6654(1)$ & $43(1)$ \\
\hline $\mathrm{C} 2$ & $7741(1)$ & $-1759(1)$ & $4190(1)$ & $46(1)$ & $7164(1)$ & $901(1)$ & $6462(1)$ & $41(1)$ \\
\hline $\mathrm{C} 3$ & $7263(1)$ & $-2765(2)$ & $4338(1)$ & $48(1)$ & 6933(1) & $1122(2)$ & $7177(1)$ & $43(1)$ \\
\hline $\mathrm{C} 4$ & 7794(1) & $-3329(2)$ & $5067(1)$ & $65(1)$ & $7431(1)$ & $369(2)$ & $7825(1)$ & $53(1)$ \\
\hline C5 & $8721(1)$ & $-3487(2)$ & $5177(2)$ & $67(1)$ & $8366(1)$ & $272(2)$ & $7967(1)$ & $57(1)$ \\
\hline $\mathrm{C} 6$ & $9127(1)$ & $-2416(2)$ & $5078(1)$ & $54(1)$ & $8526(1)$ & $37(1)$ & $7231(1)$ & $46(1)$ \\
\hline $\mathrm{C} 7$ & $7262(1)$ & $-1341(2)$ & $3384(1)$ & $53(1)$ & $6748(1)$ & $1753(1)$ & $5853(1)$ & 41(1) \\
\hline $\mathrm{C} 8$ & $6864(1)$ & $-336(2)$ & $3253(2)$ & $74(1)$ & $6128(1)$ & $1482(2)$ & $5148(1)$ & $51(1)$ \\
\hline C9 & $6408(2)$ & $13(3)$ & $2507(3)$ & $105(1)$ & $5748(1)$ & $2272(2)$ & $4604(1)$ & $62(1)$ \\
\hline $\mathrm{C} 10$ & $6344(2)$ & $-619(5)$ & 1902(2) & $120(2)$ & $5983(1)$ & $3338(2)$ & $4751(1)$ & 61(1) \\
\hline $\mathrm{C} 11$ & 6733(2) & $-1601(4)$ & $2018(2)$ & $104(1)$ & $6605(1)$ & $3619(2)$ & $5446(1)$ & $58(1)$ \\
\hline $\mathrm{C} 12$ & $7195(2)$ & $-1967(3)$ & $2759(1)$ & $75(1)$ & 6981(1) & $2831(2)$ & 5992(1) & 49(1) \\
\hline $\mathrm{C} 13$ & $10079(1)$ & $-2561(2)$ & $5234(1)$ & $55(1)$ & $9490(1)$ & $-32(1)$ & $7426(1)$ & $47(1)$ \\
\hline $\mathrm{C} 14$ & $10690(2)$ & $-2015(2)$ & $5829(1)$ & $67(1)$ & 9992(1) & $880(2)$ & $7541(1)$ & $66(1)$ \\
\hline $\mathrm{C} 15$ & $11563(2)$ & $-2149(2)$ & 5982(2) & $83(1)$ & $10875(1)$ & $808(2)$ & $7757(1)$ & $71(1)$ \\
\hline $\mathrm{C} 16$ & $11833(2)$ & $-2825(3)$ & $5543(2)$ & $85(1)$ & $11271(1)$ & $-173(2)$ & $7871(1)$ & $65(1)$ \\
\hline $\mathrm{C} 17$ & $11240(2)$ & $-3375(2)$ & $4954(2)$ & $86(1)$ & $10786(2)$ & $-1085(2)$ & $7767(2)$ & 84(1) \\
\hline $\mathrm{C} 18$ & 10367(2) & $-3250(2)$ & $4796(2)$ & $74(1)$ & $9897(1)$ & $-1016(2)$ & $7541(2)$ & $73(1)$ \\
\hline $\mathrm{C} 19$ & $6330(1)$ & $-2520(2)$ & $4248(1)$ & $53(1)$ & $5954(1)$ & $1156(2)$ & 6992(1) & $57(1)$ \\
\hline $\mathrm{C} 20$ & $5796(2)$ & $-3547(2)$ & $4179(2)$ & $83(1)$ & $5741(2)$ & $1617(3)$ & $7651(2)$ & $78(1)$ \\
\hline $\mathrm{C} 21$ & $6246(2)$ & $-1763(3)$ & $4850(2)$ & $80(1)$ & $5507(2)$ & $76(3)$ & $6723(2)$ & $89(1)$ \\
\hline $\mathrm{C} 22$ & $9058(2)$ & $-967(2)$ & $4205(2)$ & $72(1)$ & $8278(2)$ & $644(2)$ & $5956(1)$ & $66(1)$ \\
\hline $\mathrm{O} 23$ & $7508(1)$ & $-3636(2)$ & $5538(1)$ & $113(1)$ & $7109(1)$ & $-117(1)$ & $8206(1)$ & $88(1)$ \\
\hline
\end{tabular}

$U_{\mathrm{eq}}=(1 / 3) \sum_{i} \Sigma_{j} U_{i j}\left(a_{i}{ }^{*} a_{j}^{*}\right)\left(\boldsymbol{a}_{i} \cdot \boldsymbol{a}_{j}\right)$.

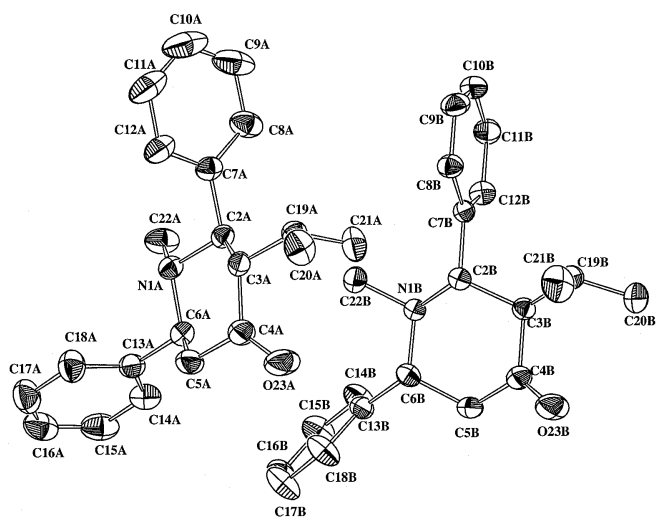

Fig. 2 Perspective view of the molecules (A and B) showing the thermal ellipsoids drawn at the $30 \%$ probability level.

value of $0.177 \AA$. ZORTEP plots of the molecules are shown in Fig. 2. A study of the torsion angles, asymmetric parameters and least-squares plane calculations ${ }^{3}$ reveals that the piperidine rings adopt the chair conformation. ${ }^{4}$ The atoms $\mathrm{C} 2$ and $\mathrm{C} 5$ deviate by $-0.617(2)$ and $0.666(2) \AA$ and $0.653(2)$ and $-0.630(2) \AA$ in molecules $\mathrm{A}$ and $\mathrm{B}$ respectively, from the best plane of the other atoms (N1, C3, C4 and C6) in the piperidine
Table 3 Possible hydrogen bonds

\begin{tabular}{ccccc}
\hline $\mathrm{D}-\mathrm{H} \cdots \mathrm{A}$ & $(\mathrm{D}-\mathrm{H}) \AA$ & $(\mathrm{D} \cdots \mathrm{A}) \AA$ & $(\mathrm{H} \cdots \mathrm{A}) \AA$ & \multicolumn{1}{c}{$(\mathrm{D}-\mathrm{H} \cdots \mathrm{A})^{\circ}$} \\
\hline $\mathrm{C} 20 \mathrm{~A}-\mathrm{H} 44 \ldots \mathrm{O} 23 \mathrm{~A}^{\mathrm{i}}$ & $1.027(2)$ & $3.034(3)$ & $2.414(6)$ & $118(2)$ \\
$\mathrm{C} 21 \mathrm{~A}-\mathrm{H} 42 \ldots \mathrm{O} 23 \mathrm{~A}^{\mathrm{i}}$ & $0.951(1)$ & $3.071(4)$ & $2.480(2)$ & $120(2)$ \\
$\mathrm{C} 20 \mathrm{~B}-\mathrm{H} 21 \ldots \mathrm{O} 23 \mathrm{~B}^{\mathrm{i}}$ & $0.960(3)$ & $3.017(4)$ & $2.450(1)$ & $118(2)$ \\
$\mathrm{C} 21 \mathrm{~B}-\mathrm{H} 47 \ldots \mathrm{O} 23 \mathrm{~B}^{\mathrm{i}}$ & $0.981(1)$ & $3.071(3)$ & $2.396(1)$ & $117(2)$ \\
$\mathrm{C} 3 \mathrm{~A}-\mathrm{H} 9 \ldots \mathrm{O} 23 \mathrm{~B}^{\mathrm{ii}}$ & $0.942(2)$ & $3.319(3)$ & $2.396(1)$ & $166(2)$ \\
$\mathrm{C} 20 \mathrm{~A}-\mathrm{H} 37 \ldots \mathrm{O} 23 \mathrm{~B}^{\mathrm{ii}}$ & $0.992(6)$ & $3.715(5)$ & $2.881(8)$ & $142(3)$ \\
$\mathrm{C} 11 \mathrm{~B}-\mathrm{H} 19 \ldots \mathrm{O} 23 \mathrm{~A}^{\mathrm{iii}}$ & $0.990(3)$ & $3.687(3)$ & $2.726(4)$ & $164(2)$ \\
$\mathrm{C} 16 \mathrm{~B}-\mathrm{H} 25 \ldots \mathrm{Cg} 1^{\mathrm{i}}$ & 0.939 & 3.938 & 3.252 & 131.6 \\
$\mathrm{C} 16 \mathrm{~A}-\mathrm{H} 33 \ldots \mathrm{Cg} 2^{\mathrm{v}}$ & 0.971 & 3.892 & 3.159 & 133.6 \\
$\mathrm{C} 5 \mathrm{~B}-\mathrm{H} 17 \ldots \mathrm{Cg} 3^{\text {vi }}$ & 0.985 & 3.811 & 3.004 & 139.8 \\
\hline
\end{tabular}

Equivalent positions: (i) $x, y, z$; (ii) $x,-y-1 / 2, z-1 / 2$; (iii) $x, y+1$, $z$; (iv) $-x, 1 / 2+y, 1 / 2-z$; (v) $-x,-1 / 2+y, 1 / 2-z$; (vi) $-x, 1-y,-z$. $\mathrm{Cg}$ is the centroid of the benzene ring: $\mathrm{Cg} 1=\mathrm{C} 7 \mathrm{~A}$ through $\mathrm{C} 12 \mathrm{~A}$; $\mathrm{Cg} 2=\mathrm{C} 7 \mathrm{~B}$ through $\mathrm{C} 12 \mathrm{~B} ; \mathrm{Cg} 3=\mathrm{C} 13 \mathrm{~A}$ through $\mathrm{C} 18 \mathrm{~A}$

ring. The piperidine rings in molecules A and B are oriented at an angle of $42.8(1)^{\circ}$ with each other.

The planar phenyl rings substituted at the 2,6 positions ${ }^{4}$ adopt an equatorial orientation to the piperidine ring, which is evidenced from the torsion angles [(C4-C5-C6-C13=) 176.7(2) and 179.1(2) $)^{\circ}$ and (C4-C3-C2-C7=) 169.4(2) and $-172.8(1)^{\circ}$ for molecules $\mathrm{A}$ and $\mathrm{B}$, respectively]. The phenyl rings (C7 through $\mathrm{C} 12)$ are oriented at angles of 89.9(1) and 89.1(3) ${ }^{\circ}$ and the phenyl rings $(\mathrm{C} 13$ through $\mathrm{C} 18)$ are oriented at angles of 75.3(1) and $61.9(1)^{\circ}$ from the plane of the piperidine ring, respectively, for molecules A and B.

The isopropyl group is substituted equatorially ${ }^{4}$ [(C5-C4-C3-C19=)-175.5(2) and 175.6(2) ; (N1-C2-C3-C19=) $177.8(2)$ and $-179.9(2)^{\circ}$ for $\mathrm{A}$ and $\mathrm{B}$, respectively. The $\mathrm{N}$ atoms in the piperidine ring of both molecules show $\mathrm{sp}^{3}$ hybridization, which can be seen from the angles around N1A and N1B $\left(329.2^{\circ}\right.$ and $\left.329.9^{\circ}\right)$. The $N$-methyl groups take an equatorial orientation to the best plane of the piperidine ring, which are seen from the torsion angles [C22-N1-C2-C3=] $-176.2(1)$ and $179.2(2)^{\circ}$ and [C22-N1-C6-C5=] -178.5(2) and 179.1(2) ${ }^{\circ}$ for the molecules A and B.

The molecules are packed in a discrete fashion and are stabilized by the $\mathrm{C}-\mathrm{H} \cdots \mathrm{O}$ type of intra and intermolecular hydrogen bonds. Interestingly, three $\mathrm{C}-\mathrm{H} \cdots \pi$ weak interactions ${ }^{5}$ stabilize the molecules in the unit cell. The details of the hydrogen bondings are given in Table 3 .

\section{References}

1. A. F. Casy and R. R. Ison, J. Pharm. Pharmacol., 1970, 22, 270.

2. O. P. W. Robinson, Postgrad. Med. J., 1973, 49, 9.

3. M. Nardelli, J. Appl. Cryst., 1995, 28, 659.

4. N. Sampath, S. M. Malathy Sony, M.N. Ponnuswamy, and M. Nethaji, Acta Cryst., 2003 C54, o346.

5. G. R. Desiraju, Acc. Chem. Res., 1996, 29, 441. 